\title{
ANTROPOLOGIA TRYCHOTOMICZNA ORYGENESA
}

Ojciec Święty Benedykt XVI w swoich katechezach środowych mówił, że Orygenes jest ,jedną z najważniejszych postaci dla całego rozwoju myśli chrześcijańskiej”' . Biblia stanowiła dla Orygenesa źródło i szczyt wiedzy prawdziwej. Studiował ją z pasją i tak też ją komentował. Hans Urs von Balthasar napisał, że dla katechety z Aleksandrii ,podłożem i centralnym punktem najgłębszego kręgu myśli jest zarówno namiętna jak i czuła miłość do Słowa"2. Biblia stała się dla Orygenesa przedmiotem bezwarunkowej czci i podstawowym argumentem przepowiadania, a przez to pożywieniem duszy, fundamentem wiary i jądrem teologii. Jako taka miała dla niego charakter normatywny we wszelkiej wiedzy i mądrości. Jego teologia miała więc charakter wybitnie biblijny, gdyż Słowo Boże było szczytem mądrości i wszystko miało służyć zrozumieniu Słowa Bożego. Niektórzy badacze Orygenesa podkreślają, że jego myśl miała charakter słowocentryczny.

1. Podstawy trychotomicznego podziału. Kiedy Orygenes czyta słowa świętego Pawła: „sam Bóg pokoju niech was całkowicie uświęca, aby nienaruszony duch wasz, dusza i ciało bez zarzutu przygotowały się na przyjście Pana naszego Jezusa Chrystusa" (1Tes 5, 23), jest to dla niego absolutnie wiążące. W Homiliach o Księdze Kapłańskiej mówi:

„[...] wiadomo, że to dusza sieje w ciele albo w duchu i że to ona może popaść w grzech albo nawrócić się z grzechu. Ciało bowiem towarzyszy jej, duch natomiast jest jej przewodnikiem na drodze ku cnocie, jeśli ona zechce za nim podążać”.

Takie wyliczenie elementów składających się na człowieka było obecne u większości Ojców poprzedzających Orygenesa. Pewną systematyzację tej

\footnotetext{
* Bp dr hab. Piotr Turzyński - adiunkt w Katedrze Patrologii Greckiej i Łacińskiej w Instytucie Historii Kościoła i Patrologii na Wydziale Teologii Katolickiego Uniwersytetu Lubelskiego Jana Pawła II; e-mail: pturzynski@episkopat.pl.

${ }^{1}$ Benedykt XVI, Ojcowie Kościoła. Od Klemensa Rzymskiego do Augustyna, Poznań 2008, 41.

${ }^{2}$ H.U. von Balthasar, Wstęp, w: Orygenes, Duch i ogień, red. H.U. von Balthasar, thum. S. Kalinkowski, BOK 4, Kraków - Warszawa 1995, 16.

${ }^{3}$ Origenes, In Leviticum hom. 2, 2, PG 14, 414, tłum. S. Kalinkowski, PSP 31/2, Warszawa 1984, 14-15.
} 
doktryny usiłował podać Ireneusz ${ }^{4}$. Orygenes idąc za tą biblijną koncepcją utrzymuje ją przez całe życie. Niestety taka antropologia zanika szybko po jego śmierci i nie podejmą jej jego wielcy uczniowie, ani Dydym Ślepy, ani Ewagriusz Pontus. Jakieś echo tej biblijnej i Orygenesowej nauki pozostanie jednak w całej teologii Wschodu ${ }^{6}$. Warto jednak zauważyć, że trychotomia u Aleksandryjczyka łączy się z dychotomicznym podziałem na człowieka wewnętrznego i zewnętrznego ${ }^{7}$, a w związku z tym cała jego antropologia wydaje się bardzo zawiła i skomplikowana. W Homilii o Księdze Rodzaju znajdujemy takie stwierdzenia:

„Jednakże tego człowieka, który zgodnie ze słowami Pisma został stworzony «na obraz Boga», nie pojmujemy jako istoty cielesnej. Istota cielesna bowiem nie zawiera w sobie obrazu Boga, a o człowieku cielesnym nie powiedziano, że «został stworzony», lecz że «został ulepiony» (por. Rdz 2, 7) [...]. Ten zaś, który został stworzony «na obraz Boga», to nasz człowiek wewnętrzny - niewidzialny, niecielesny, niezniszczalny i nieśmiertelny [...]. Kto zaś sądzi, że cielesną istotą jest człowiek, który został stworzony «na obraz i podobieństwo Boże», ten, jak się zdaje, samego Boga przedstawia jako byt cielesny i mający ludzką postać, a taka myśl o Bogu jest oczywistą bezbożnością"”.

Orygenes oscyluje między dualizmem platońskim rozdzielającym człowieka na duszę i ciało z jego sferą zmysłowa, a Pawłowym podziałem na ducha, duszę i ciało ${ }^{9}$. Komentując w dziele De principiis tekst św. Pawła z Listu do Galatów $(5,17)$ : ,jeśli ciało walczy przeciwko duchowi, a duch przeciw ciału, to nie czynimy tego, co chcemy" - Orygenes mówi:

„O cóż więc chodzi w słowach: «nie czynimy tego co chcemy»? Powiadają: Z pewnością nie o duchu tu mowa, bo nic nie stoi na przeszkodzie woli ducha; również i nie o ciele, bo jeśli nie ma ono własnej duszy, to nie posiada też i woli; pozostaje jedna ewentualność - chodzi tu o wolę duszy, która może posiadać własną wolę walczącą z wolą ducha. A skoro tak, to wiadomo, że wola tej duszy jest czymś pośrednim między ciałem i duchem, a bez wątpienia służy ona i jest posłuszna albo ciału, albo duchowi - temu, któremu chce być posłuszna: kiedy podda się rozkoszom cielesnym, tworzy cielesnych

\footnotetext{
${ }^{4}$ Por. H. Crouzel, Orygenes, thum. J. Margański, Kraków 2004, 124. Zob. H. De Lubac, Theology in history, San Francisco 1996, 130-136.

${ }^{5}$ Por. Crouzel, Orygenes, s. 124.

${ }^{6}$ Por. T. Špidlik, Duchowość chrześcijańskiego wschodu, thum. L. Rodziewicz, Kraków 2005, 129.

${ }^{7}$ Por. M. Składanowski, Ciało. Dusza. Duch. Myśl Ratzingera na tle wspótczesnej antropologii, Warszawa 2013, 41.

${ }^{8}$ Origenes, In Genesim hom. 1, 13, red. L. Doutreleau, SCh 7bis, Paris 1956, 56-58, thum. S. Kalinkowski, PSP 31/1, Warszawa 1984, 33.

${ }^{9}$ Por. M. Szram, Od obrazu do podobieństwa Bożego. Dynamiczna koncepcja antropologii teologicznej w II-III wieku, VoxP 22 (2002) t. 42-43, 370.
} 
ludzi, kiedy zaś połączy się z duchem, sprawia, że człowiek tkwi w duchu i dlatego nazywa się człowiekiem duchowym" $"$.

Podział trychotomiczny człowieka pozwala Aleksandryjczykowi interpretować poprawnie Słowo Boże i Pawłową teologię, a bez wątpienia pokazuje teologiczną wizję człowieka.

Według Tomasa Špidlika trójczęściowy podział człowieka pochodzi od Posydoniusza $^{11}$ i znajdziemy go u Arystotelesa i u perypatetyków ${ }^{12}$. U Grzegorza z Nazjanzu taka trychotomia jest uważana za powszechnie przyjętą ${ }^{13}$. Jednak według Henri Crouzela trychotomicznego podziału Orygenesa nie można wyprowadzić z trychotomii Platona, gdyż u Orygenesa dotyczy ona całego człowieka, a u Platona tylko duszy ${ }^{14}$. Za Platonem idzie natomiast Klemens Aleksandryjski mówiąc o trzyczęściowej duszy ${ }^{15}$. Świat semicki mówi także o ciele, duszy (שפנ) i (זרור) w człowieku. Według wspomnianego Špidlika ten biblijny trychotomiczny podział nie ma charakteru analitycznego, lecz syntetyczny ${ }^{16}$. Podział ten mówi o różnych aspektach ludzkiej egzystencji. Człowiek jest ciałem, gdyż jest stworzeniem, które umiera, a przez ciało komunikuje ze światem materialnym, jest duszą, ponieważ żyje i oddycha oraz jest duchem, który otwiera go ku Bogu.

Antropologia Orygenesa przenika się wzajemnie z rozumieniem i egzegezą Słowa Bożego. Manlio Simonetti zauważa, że komentarze biblijne Orygenesa nie przypominają greckich komentarzy literalnych, ale są podobne do komentarzy Filona Aleksandryjskiego i hermeneutyki z greckich szkół filozoficznych ${ }^{17}$. W De principiis Aleksandryjczyk przedstawił egzegezę biblijną właśnie w połączeniu z trychotomicznym podziałem człowieka ${ }^{18}$, a to z kolei łączy się z podziałem chrześcijan na simpliciores, progredientes i perfecti ${ }^{19}$. W integralną całość łączy się także u Orygenesa wizja historii zbawienia, która rozwija się poprzez prawo, proroków i znajduje swoje wypełnienie w Nowym

${ }^{10}$ Origenes, De principiis III 4, 2, PG 11, 320, tłum. S. Kalinkowski, ŹMT 1, Kraków 1996, 296-297.

${ }^{11}$ Posydoniusz (135-50 prz. Chr.) filozof grecki łączył filozofię stoicką z platonizmem i mistycyzmem; obliczył obwód Ziemi; jako historyk opisał w 52 tomach dzieje w okresie 144-82 prz. Chr.

${ }^{12}$ Por. Špidlik, Duchowość chrześcijańskiego wschodu, s. 130.

${ }^{13}$ Por. Gregorius Nazianzenus, Carmina 1, 1, 10.

${ }^{14}$ Por. Crouzel, Orygenes, s. 124.

${ }^{15}$ Por. Clemens Alexandrinus, Stromata V 73, 2. Zob. Špidlik, Duchowość chrześcijańskiego wschodu, Kraków, s. 130, nota 57; S. Swieżawski, Dzieje europejskiej filozofii klasycznej, Warszawa - Wrocław 2000, 285.

${ }^{16}$ Por. T. Špidlik - I. Gargano, La spiritualità dei Padri greci e orientali, Roma 1983, 74.

${ }^{17}$ Por. M. Simonetti, Między dostownościq a alegoriq, tłum. T. Skibiński, Kraków 2000, 74.

${ }^{18}$ Por. Origenes, De principiis IV 2, 4, ŹMT 1, 340: „Jak zatem mówimy, że człowiek składa się z ciała, duszy i ducha, tak samo i Pismo Święte, którego szczodrobliwość Boża udzieliła dla zbawienia ludzi”.

${ }^{19}$ Por. Simonetti, Między dostownościq a alegoria, s. 80. 
Testamencie ${ }^{20}$. Antropologia nie jest więc u niego wyizolowana, ale komponuje się z całą wizją teologiczną.

2. Duch. Warto przyjrzeć się poszczególnym elementom ludzkiego bytu w ujęciu Orygenesa i spróbować zrozumieć ich funkcje i znaczenie. Dla Aleksandryjczyka duch obecny w strukturze człowieka jest pierwiastkiem boskim, ale jako dar Boży nie bierze odpowiedzialności za grzechy ${ }^{21}$. Henri Crouzel uważa, że $\pi v \varepsilon \hat{v} \mu \alpha$ jest u Aleksandryjczyka wyłącznie koncepcją biblijną pochodzącą od starotestamentowego ruah (חוּר) i jest absolutnie niematerialne. Grecy natomiast nadawali duchowi delikatną, trudno uchwytną materialność 22 . Ten element jest nauczycielem duszy, a raczej jej wyższego elementu, który Orygenes utożsamia z rozumem i inteligencją (vô̂s). W duchu znajduje się świadomość moralna i sumienie. Duch jako nadrzędny w stosunku do duszy pomaga jej w zdobywaniu cnót i chociaż czyni ją bardziej duchową, nie zabiera jej jednak wolności ${ }^{23}$. Duch jest najwyższą strukturą ontyczną w człowieku i stanowi jego otwartość na działanie Boga i zawsze stanowi podstawę możliwości zmiany i nawrócenia. Ten element ontycznej struktury człowieka przechowuje w sobie owoce Ducha Świętego (por. Ga 5, 22) i cnoty ${ }^{24}$. Duch, przebywając w człowieku, rozjaśnia mu prawdę, gdy ten jej szuka i bada ją ${ }^{25}$. Jest on jednak różny od Ducha Świętego, ,stanowi formę wykreowanego w Nim uczestnictwa i Jego miejsce"26 w człowieku. Byłby duch w ujęciu Orygenesa raczej czymś, co scholastyka nazwała łaską uświęcająca, przy czym jest obecny w każdym człowieku, nawet w nieochrzczonym i nie opuszcza go, gdy ten pogrąża się w największych nawet grzechach, ale pozostaje w stanie pewnego uśpienia, czy odrętwienia, jako wezwanie i możliwość dobra. „Duch - ów Logos nasienny - pełni w człowieku funkcję wychowawcy i nauczyciela"27. Orygenes jest przekonany, że dusza pod wpływem ducha, staje się duchowa ${ }^{28}$. W Komentarzu do Psalmów znajdujemy stwierdzenie wydobyte przez Balthasara w antologii tekstów Orygenesa: „dusza, która na skutek grzechu stała się ciałem, ulegnie przemianie i będzie duchem"29. Taka wewnętrzna możliwość

${ }^{20}$ Por. Origenes, In Leviticum hom. 1, 4.

${ }^{21}$ Por. Crouzel, Orygenes, s. 124.

${ }^{22}$ Por. tamże.

${ }^{23}$ Por. S. Kaczmarek, Darowanie win. Orygenesowa egzegeza przypowieści o nielitościwym dtużniku (Mt 18, 23-35) i wezwania Modlitwy Pańskiej (Mt 6, 12; Łk 11, 4) wraz z jej uzupetnieniem (Mt 6, 14-15), Kraków 2005, 254.

${ }^{24}$ Por. Origenes, In Leviticum hom. $2,2$.

${ }^{25}$ Por. tenże, Fragmenta e catenis in Epistulam primam ad Corinthios, BOK 4, 185 (nr 449).

${ }^{26}$ Por. Crouzel, Orygenes, s. 125.

${ }^{27}$ J. Zieliński, Jerozolima, Ateny, Aleksandria. Greckie źródła pierwszych nurtów filozofii chrześcijańskiej, Wrocław 2000, 236.

${ }^{28}$ Por. Origenes, De oratione 10.

${ }^{29}$ Tenże, Libri in Psalmos 64, 3, PG 12, 1493, BOK 4, 143 (nr 335). 
przemiany wskazywałaby raczej na moralno-duchowy charakter trychotomicznej antropologii niż jej ontologiczne rozumienie. Henri de Lubac definiuje ten najwyższy element człowieka jako ,pewną transcendencję człowieka poza siebie”30. Jeśli dusza ożywia ciało i czyni je „duszą żyjącą”, to używając słów Paula Evokimova, „duch uduchawia cały byt ludzki”31.

Równocześnie dla Orygenesa ontyczną jakością wyróżniającą człowieka spośród innych bytów jest stworzenie na obraz i podobieństwo Boga. Idea obrazu Boga w człowieku była obecna już u Filona Aleksandryjskiego i potem u większości Ojców przed i po Orygenesie. Dla chrześcijan myśl ta współgrała z licznymi tekstami św. Pawła, który nazywa Chrystusa obrazem Boga Ojca (np. Kol 1, 15). Aleksandryjczyk twierdzi, że tylko Chrystus w sensie właściwym jest obrazem Boga i to obrazem perfekcyjnym poprzez swoją boskość, jest obrazem niewidzialnym Boga niewidzialnego ${ }^{32}$. Człowiek natomiast jest stworzony według obrazu Boga, jakim właśnie jest Słowo. Człowiek jest „obrazem Obrazu" albo według często używanego określenia Aleksandryjczyka, człowiek jest „według Obrazu Boga”. Według Mariusza Szrama Orygenes jest reprezentantem tradycji aleksandryjskiej, w której obrazem Boga nie jest człowiek integralny, ale raczej dusza czy vô̂ৎ, albo idąc za tradycją stoików

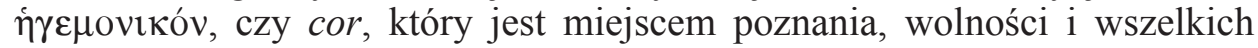
cnót $^{33}$. Wydaje się, że Orygenes nie jest tak jednoznaczny i można postawić pytanie czy obraz Boga w człowieku nie zasadza się raczej na posiadaniu tego boskiego elementu, jakim jest właśnie duch.

W dziele De principiis Orygenes, opierając się na tekstach biblijnych jednoznacznie wprowadza podział na statyczny obraz i dynamiczne podobieństwo. Konstatuje:

„[...] mówił na ten temat Mojżesz: «I powiedział Bóg: Uczyńmy człowieka na obraz i podobieństwo nasze» (Rdz 1, 26), a zaraz dalej dodał: «I uczynił Bóg człowieka na obraz swój, mężczyzną i niewiastą uczynił ich i błogosławił im» (Rdz 1, 27). Fakt, że Mojżesz mówiąc: «Uczynił go na obraz swój» przemilczał sprawę podobieństwa, wskazuje właśnie na to, że w chwili pierwszego stworzenia człowiek otrzymał godność «obrazu Bożego», natomiast doskonałe «podobieństwo do Boga» zostało zarezerwowane dla niego na koniec: chodzi o to, by człowiek zdobył je sobie własnym wysiłkiem przez naśladowanie Boga" ${ }^{34}$.

Wydaje się, że wzajemna relacja obrazu Boga w człowieku do istniejącego w nim podobieństwa do Boga jest podobna do relacji między statycznie

${ }^{30}$ H. de Lubac, Histoire et Esprit. L'inteligence de l'Écriture d'après Origène, Paris 1950, 157, thum. własne.

${ }^{31}$ P. Evdokimov, Prawostawie, Warszawa 2003, 70.

${ }^{32}$ Por. Crouzel, Orygenes, s. 130.

${ }^{33}$ Por. Szram, Od obrazu do podobieństwa Bożego, s. 369.

${ }^{34}$ Origenes, De principiis III 6, 1, PG 11, 540, ŹMT 1, 310-311. 
rozumianym duchem, jako istotnym elementem ludzkiego bytu, a dynamicznie ujętą duszą ludzką z jej wyższą władzą skierowaną właśnie ku duchowi. Człowiek uczestniczy w Bogu, jako Bogu, a jego diwinizacja może rozwijać się dzięki działaniu Syna, aż do pełnego upodobnienia się do Obrazu Boga w wiecznej szczęśliwości. Idea uczestnictwa ma charakter dynamiczny: obraz dąży do osiagnięcia Modelu i do maksymalnego podobieństwa. To bycie obrazem Obrazu czy stworzeniem według Obrazu wydaje się według Orygenesa być podstawową substancją $a^{35}$ i głębią ludzkiej natury. Człowiek definiuje się w swojej relacji do Boga oraz poprzez wewnętrzną siłę, która wprawia go w ruch i popycha w kierunku jego Modelu. Na każdym etapie tego ruchu nade wszystko można zaobserwować z jednej strony łaskę Boga a z drugiej wolność człowieka. Pojęcie wolności nie redukuje się jednak do wolnej woli, gdyż Orygenes w swojej doktrynie duchowej podkreśla za św. Pawłem, że przylgnięcie do Boga wyzwala, a odrzucenie zniewala go. Jeśli duch jest tym elementem statycznym decydującym o byciu na obraz Obrazu i o człowieczeństwie, to zbliżanie się duszy ku duchowi jest procesem upodabniania do Boga i zależy od woli człowieka. Może dlatego idąc za Orygenesem i całą tradycją wschodnią Włodzimierz Łosski, rozważając o Duchu Świętym i o życiu Bożym w człowieku powie, że to zamieszkiwanie Ducha w człowieku decyduje o naturze ludzkiej i byciu osobą, bowiem On „utożsamia się tajemniczo z osobami ludzkimi, pozostając przy tym nieudzielny"36.

W myśli Orygenesa wolność człowieka decyduje jednak o możliwości grzechu. Kiedy „obraz Obrazu” zacznie działać w kierunku przeciwnym niż ten, który prowadzi go do Archetypu, grzech zakrywa obraz innymi wyobrażeniami, czy też w pewien sposób ukrywa go pod warstwą pleśni. Obraz jednak, jako utworzony przez wieczny Logos, nie może być starty. Jego trwałość i obecność ducha w strukturze ludzkiego bytu, dzięki łasce Chrystusa, pozostawiaja zawsze możliwość powrotu i nawrócenia. Orygenes wyraźnie podkreśla, że po grzechu pierwszych rodziców człowiek nie utracił obrazu Boga $\mathrm{w}$ sobie, ale obraz ten został poważnie zabrudzony ${ }^{37}$. Jego odnowienie jest możliwe dzięki zamieszkiwaniu Logosu w duszy. Dynamika przemiany i rozwoju człowieka ma wyraźnie walor etyczny. Chrzest oczyszcza z grzechów i przywraca przejrzystość obrazu, a praktyka cnót i słuchanie Słowa Bożego rodzą w sercu Chrystusa i pozwalają się do Niego upodobnić.

Obraz Boga w człowieku łączy się z rzeczywistością dynamiczną, jaką jest podobieństwo, które istnieje niejako w zarodku. Maksymalne podobieństwo, które byłoby poznaniem Chrystusa i Boga jest zarezerwowane na koniec czasów. Takie thumaczenie jest usprawiedliwione wypowiedzią św. Jana, w której Apostoł wskazuje, że gdy przyjdzie Chrystus ,będziemy do Niego podobni,

\footnotetext{
${ }^{35}$ Por. tenże, Commentarii in Ioannem 20, 22 (20), 182.

${ }^{36}$ W. Łosski, Teologia mistyczna Kościoła wschodniego, Kraków 2007, 165.

${ }^{37}$ Por. Origenes, In Genesim hom. 9, 2.
} 
gdyż ujrzymy Go takim, jakim jest" (1J 3, 2) $)^{38}$. Droga człowieka, jako obrazu Obrazu, ku upodobnieniu jest drogą rozwoju duchowego. Według Orygenesa Logos tworzy swojego wiernego tak jak Jezus, jeszcze w łonie Maryi, zaniesiony do Elżbiety, kształtuje Jana ${ }^{39}$. Jednym $\mathrm{z}$ wielkich tematów mistycznych Orygenesa jest kształtowanie się Chrystusa w człowieku wierzącym. Warto pamiętać, że Logos kształtuje się w człowieku wewnętrznym przede wszystkim na podstawie praktyki cnót. Aleksandryjczyk jest przekonany, że Chrystus jest szczytem i wcieleniem wszelkich cnót ${ }^{40}$. Temat cnoty powszechny u starożytnych filozofów znajduje więc miejsce u Orygenesa a potem przechodzi także do autorów zachodnich, a wśród nich także do Augustyna z Hippony ${ }^{41}$. Praktyka cnót, w której nie można posiadać jednej bez posiadania wszystkich, jest uczestnictwem egzystencjalnym w Osobie Jezusa Chrystusa. To uczestnictwo i kontemplacja Jego chwały prowadzi ostatecznie do transformacji w Chrystusa.

3. Dusza. Broniąc chrześcijan przed atakami Celsusa, Orygenes pisze:

„wyraźnie przecież mówimy, że dusza, zwłaszcza dusza rozumna jest cenniejsza od wszelkiego ciała, albowiem właśnie dusza, a nie ciało posiada pieczęć odciśniętą na obraz Stworzyciela"42.

Według Aleksandryjczyka dusza zawiera w sobie coś z elementu wyższego - $\mathrm{z}$ ducha, i coś $\mathrm{z}$ elementu niższego - $\mathrm{z}$ ciała. Właściwie chodzi raczej tu o dwie tendencje istniejące w duszy, które sprawiają, że oscyluje ona między duchem a ciałem. Według Henri Crouzela trychotomiczna antropologia Orygenesa posiada raczej charakter dynamiczny a nie ontologiczny w sensie ścisłym $^{43}$. Dusza jest siedzibą wolnej woli, która posiada siłę dokonywania wyboru i rzeczywiście decyduje o człowieku, stanowiąc niejako podstawę jego osobowości. Dusza jest centrum decyzyjnym. Jeżeli się dostosowuje do ducha, staje się podobna do niego, cała duchowa, nawet ze swoim elementem niższym. Może również odrzucić ducha i wtedy zwraca się do ciała i odbiera elementowi wyższemu jego dominację, staje się cała cielesna, oczywiście nie w sensie dosłownym. Dla Orygenesa i większości wschodnich Ojców Kościoła cały człowiek zmienia się do głębi w zależności od swojej relacji z Bogiem. Według Aleksandryjczyka element wyższy duszy konstytuował ją w jej stanie pre-egzystencji, czyli istnienia w czasie zanim połączyła się z ciałem.

${ }^{38}$ Por. tenże, De principiis III $6,1$.

${ }^{39}$ Por. tenże, Commentarii in Ioannem VI 49, 252.

${ }^{40}$ Por. Crouzel, Orygenes, 135.

${ }^{41}$ Por. Augustinus, Enarrationes in Ps. 83, 11, ed. D.E. Dekkers - I. Frainpont, CCL 39, Turnholti 1956, 1157: „Multae virtutes, sed hic necessariae; et ab hic virtutibus imus in vitutem. Quam virtutem? Christum, Dei virtutem, et Dei sapientiam".

${ }^{42}$ Origenes, Contra Celsum VIII 49, ed. M. Borret, SCh 150, Paris 1969, 282, thum. S. Kalinkowski: Orygenes, Przeciw Celsusowi, Warszawa 1986, 409.

${ }^{43}$ Por. Crouzel, Orygenes, s. 124. 
Preegzystencja dusz jest praktycznie jedyną jednoznacznie wyrażoną ideą Aleksandryjczyka, z którą późniejszy Kościół się nie zgodził. Ta wyższa część duszy stworzona na podobieństwo Słowa jest w pewien sposób spokrewniona z Bogiem i staje się do Niego coraz bardziej podobna dzięki praktyce życia chrześcijańskiego. To dzięki niej człowiek modli się i kontempluje prawdy Boże. Dusza jest jednocześnie uczennicą pneumy i wskazuje na łaskę, jako dar Boży, przy czym duch jest elementem aktywnym, a wyższa część duszy inteligencja - reprezentuje aspekt pasywny i receptywny w stosunku do łaski Bożej. Ta właśnie część akceptuje, bądź nie, na mocy swojej wolnej woli, dar Boga. Dzięki takiemu rozróżnieniu Orygenes był w stanie rozwiązać problem współistnienia wolnej woli i łaski, problem, który począwszy od św. Augustyna nurtował chrześcijan wszystkich wieków. U Aleksandryjczyka, choć nie rozważa on wprost tego tematu, nie widząc prawdopodobnie problemu, istnieją więc dwa aspekty łaski: dar Boga i przyjęcie ze strony człowieka ${ }^{44}$.

Element niższy duszy został jej dodany po pierwszym grzechu i odpowiada on pewnej tendencji, która ciagle dąży do tego, by oderwać duszę od ducha i skierować ją ku ciału. Ten element jest podstawą instynktów i pasji, jakie drzemią w człowieku. W pewnym sensie można go utożsamiać z tym, co późniejsza teologia nazwie pożądliwością z tą jednak różnicą, że Orygenes przypisuje jej również czynności naturalne, które same z siebie nie są złe i mogą być wysublimowane bez zniszczenia, gdy dusza skieruje się ku duchowi. Naukę tę rozwija Orygenes także przy okazji rozważań chrystologicznych. Według Aleksandryjczyka dusza pre-egzystująca Jezusa była absolutnie bez grzechu i została dodana do wiecznego Logosu. Jednakże we wcieleniu Chrystus otrzymuje również tę część duszy, która jest skierowana ku ciału i w ten sposób jest podobny do człowieka we wszystkim oprócz grzechu. Ta niższa część jest dla Niego, tak jak i dla ludzi, podstawą cierpienia, bólu, smutku i trosk. W odnalezionym w 1941 r. dziele Orygenesa pod tytułem Rozmowa z Heraklidesem autor rozróżnia w Chrystusie ducha, duszę i ciało. Pisze:

„te trzy rozdzielają się jedno od drugiego w momencie męki i te trzy łączą się ze sobą w momencie zmartwychwstania. W momencie męki rozdzielają się jedno od drugiego. Jak? Ciało w grobie, dusza w otchłani, duch oddany Ojcu”45.

W tym samym tekście Aleksandryjczyk podkreśla, że Chrystus był prawdziwym człowiekiem i posiadał wszystkie elementy ontyczne człowieczeństwa, gdyż gdyby, jako Bóg, nie przyjął całego człowieka, nie zbawiłby całego człowieka $^{46}$. To pryncypium przejdzie do myśli chrześcijańskiej Wschodu, jako podstawowe $\mathrm{w}$ zmaganiu $\mathrm{z}$ herezjami chrystologicznymi.

${ }^{44}$ Por. tamże, s. 124-129.

${ }^{45}$ Origenes, Disputatio cum Heracleida 7, ed. J. Scherer, SCh 67, Paris 1960, 70, 14-18, thum. A. Zajkowski: Origenes, Dyskusja z Heraklidesem, STV 5 (1967) z. 2, 132.

${ }^{46}$ Por. tamże. 
Są jeszcze i inne powiązania myśli antropologicznej katechety z Aleksandrii. Jednym z oryginalnych tematów mistycznych Orygenesa jest miłość oblubieńcza Chrystusa i duszy ${ }^{47}$. W Komentarzu do Pieśni nad Pieśniami wyjaśnia tekst poematu najpierw w sensie dosłownym, a potem buduje sens alegoryczny, w którym Oblubienicą jest Kościół, ale także i dusza indywidualnego człowieka. Zaślubiny Chrystusa z Oblubienicą mają swój początek w pre-egzystencji, kiedy dusza jest zespolona z Logosem. Potem jednak w wyniku pierwotnego upadku, stosownie do zasług, pre-egzystujące dusze stają się aniołami, ludźmi i demonami. Ten upadek dzieli Oblubieńca i Oblubienicę. Na ziemi Oblubienica - dusza ludzka ma za zadanie przyciągnąc swoim pięknem Chrystusa - Oblubieńca. Orygenes pisze:

„A jeśli uzna za godne przyjść i do mojej duszy, która stała się Oblubienicą jakże ona powinna być piękna, aby pociagnnąć go do siebie z nieba, żeby spowodować jego zstapienie na ziemię, żeby przybył do ukochanej? Jakąż pięknością trzeba ją przystroić, jaką powinna płonąć miłością, aby mówił do niej to, co powiedział doskonałej Oblubienicy: «Ach twoja szyja, twoje oczy, twoje policzki, twoje ręce, twoje łono, ramiona, stopy» (Pnp 1, 10. 15; 5, 14; $7,2)[\ldots]$. W podobny sposób zwraca się Oblubieniec do naszej duszy"48.

U Orygenesa znajdziemy zaczerpnięty od św. Pawła $(\mathrm{Ga} 4,19)$ temat zamieszkiwania Chrystusa w duszy. „Wszelka dziewicza i nieskalana dusza, która poczęła się z Ducha Świętego, aby zrodzić wolę Ojca, jest matką Jezusa"49. To wiąże się z przyjmowaniem Słowa. Dusza poczyna ze Słowa, rodzi Słowo i staje się Jego mieszkaniem ${ }^{50}$. Orygenes pragnie i zachęca, by oczy duszy zawsze wpatrywały się w Chrystusa ${ }^{51}$.

4. Ciało. Trzecim elementem budującym strukturę człowieka jest ciało. Jest ono uznawane za niezbędny element składowy ludzkiego bytu, ale jednak - jak stwierdza M. Szram - ,znajduje się zdecydowanie w cieniu duszy, a tym bardziej ducha" 52 . Nie ma wątpliwości, że człowiek uczestniczy w Bogu poprzez swoją duszę a nie przez ciało, ale jak zauważa H. Crouzel dla Orygenesa ciało ma zaszczyt udziału w tej godności duszy ${ }^{53}$. Ciało jest jednak źródłem namiętności i instynktów i przez połączenie z duszą osłabia ją. Nie zmienia

\footnotetext{
${ }^{47}$ Por. Crouzel, Orygenes, s. 162-163.

${ }^{48}$ Origenes, In Canticum canticorum hom. 1, 3, PG 13, 40-41, thum. S. Kalinkowski, w: Orygenes, Komentarz do Pieśni nad Pieśniami; Homilie o Pieśni nad Pieśniami, Kraków 1994, 200.

${ }^{49}$ tenże, Fragmenta in Matthaeum 281, ed. E. Klostermann - E. Benz, GCS 41/1, Leipzig 1941, 126, tłum. J. Margański, w: Crouzel, Orygenes, s. 165.

${ }^{50}$ Por. Crouzel, Orygenes, s. 165.

${ }^{51}$ Por. Origenes, In Leviticum hom. 3, 6.

${ }^{52}$ M. Szram, Ciało zmartwychwstałe w myśli patrystycznej przełomu II i III wieku, Lublin 2010, 265.

${ }^{53}$ Por. Crouzel, Orygenes, s. 127.
} 
to faktu, że jako stworzone przez Boga samo w sobie jest dobre ${ }^{54}$. Warto jednak dodać, że Orygenesowa koncepcja ciała ( $\sigma \alpha ́ \rho \xi$, corpus/caro) jest niejasna i wieloznaczna. Chociaż wiele razy powtarza, że Trójca Święta jest absolutnie niecielesna, a ciało jest charakterystyką każdego stworzenia, to jednak wydaje się, że mówiąc o duszy bezcielesnej, jest przekonany, iż jest ona zawsze połączona z jakąś cielesnością ${ }^{55}$. Trudności w jednoznacznym rozumieniu wszystkich elementów antropologii Aleksandryjczyka wynikają z przeplatania się wątków filozoficznych z moralnym i z mistycznym rozumieniem rzeczywistości. Ciało czasami Orygenes ujmuje, jako element bytowy, a czasem mówi o cielesności, jako przylgnięciu do pożądań ciała i po prostu w powiązaniu z grzesznością. Ten ostatni aspekt pojawia się często zwłaszcza w homiliach przeznaczonych dla prostych wierzacych ${ }^{56}$. Pewien pozytywny wymiar cielesności ujmuje Orygenes podkreślając, że ciało nie jest tylko więzieniem dla duszy, ale instrumentem duszy i znakiem, przez który się wyraża. Ciało jest dla niego w pewnym sensie miejscem spotkania duszy z Bogiem ${ }^{57}$. Takiego podejścia uczy cielesność Syna Bożego Wcielonego oraz nauka o Kościele. W Komentarzu do Pieśni nad Pieśniami Orygenes pisze:

„dusza ma wspólne ze Słowem łoże - swoje ciało. Boska moc rozciaga się bowiem również na wdzięk ciała, gdy umieszcza w nim dar czystości albo łaskę stałości czy innych dobrych czynów. Rozważ nadto, czy «wspólnym łożem» Oblubienicy i Oblubieńca nie można nazwać również tego ciała, które przyjął Jezus: wydaje się przecież, iż za sprawą tego ciała Kościół został zjednoczony z Chrystusem i mógł otrzymać udział w Słowie Bożym"58.

Rozważając zagadnienie ciała zmartwychwstałego Orygenes usiłuje zachować ideę Pawłową wyrażoną obrazem ziarna i rośliny (por. 1Kor 15, 35-38). Ciało ludzkie przed zmartwychwstaniem posiada identyczność substancji, ale różność jakości. Ostatecznie ciało zmartwychwstałe upodabnia się do ciała eterycznego aniołów ${ }^{59}$. Dochodzi tu do głosu zakorzeniona u Platona i Arystotelesa filozoficzna koncepcja eteru, która oznacza część nieba ponad powietrzem i konstytuuje najczystszy stan, jaki może przyjąć istota cielesna ${ }^{60}$. W sporach późniejszych Orygenes był krytykowany i czasem wprost wyśmiewany, że mówiąc o ciele chwały uważa, iż nie będzie ono posiadało nic

${ }^{54}$ Por. Origenes, Commentarii in Ioannem 13, 42.

${ }^{55}$ Por. tenże, De principiis I 6, 4; II 2, 2; IV 3, 15.

${ }^{56}$ Por. G. Sfameni Gasparro, Corpo, w: Origene. Dizionario. La cultura, il pensiero, le opere, ed. A. Monaci Castagno, Roma 2000, 91.

${ }^{57}$ Por. Szram, Ciało zmartwychwstate, s. 254.

${ }^{58}$ Origenes, Libri X in Canticum canticorum 3, 2, PG 13, 149, thum. S. Kalinkowski, w: Orygenes, Komentarz do Pieśni nad Pieśniami, s. 126.

${ }^{59}$ Por. tenże, Commentarii in Matthaeum 17, 30.

${ }^{60}$ Por. Crouzel, Orygenes, s. 306. 
w sensie cielesności z tego świata, a więc ani narządów płciowych, ani relacji rodzinnych ${ }^{61}$. Ciało zmartwychwstałe ludzi połączone z duszą będzie podlegało Duchowi Bożemu i ustanie napięcie między władzą pożądliwą duszy a władzą ducha ${ }^{62}$. Człowiek odzyska wtedy wewnętrzną harmonię i pokój.

$$
* * *
$$

Orygenes zdobył gruntowne wykształcenie i opanował wiedzę filozoficzną swojej epoki, ale jako głęboki i wnikliwy chrześcijanin postawił na szczycie poznania znajomość Biblii, której nadawał wyjątkowe znaczenie. Niemiecki badacz Aleksandryjczyka Aloisius Lieske, a za nim inni, nazywa Orygenesa teologiem i mistykiem Logosu ${ }^{63}$. Dominującym akordem jego myśli teologicznej są zagadnienia wstępowania duszy ku Bogu, które są podstawowe także dla gnostyków i neoplatoników ${ }^{64}$. To wszystko w mniejszym lub większym zakresie determinuje jego myśl antropologiczną. Słusznie zauważa Crouzel, że trychotomiczna antropologia posiada charakter raczej moralny i ascetyczny, a treścią jej jest duchowa walka. Dusza wyposażona w wolną wolę jest tu areną zmagania między tym, co wzniosłe i duchowe, a przez to bliskie Bogu, a tym, co niskie i ziemskie. Człowiek posiadając w sobie skłonność ku obydwu pierwiastkom: duchowemu i materialnemu, równocześnie jest miejscem połączenia między obiema stronami ${ }^{65}$. To podkreśla wyjątkowość i dramatyzm człowieka. W myśli antropologicznej Orygenesa płaszczyzny moralna i ontyczna przenikają się wzajemnie, podobnie jak ujęcie dychotomiczne i trychotomiczne bytu ludzkiego. Dynamiczna wizja trychotomiczna pokazuje istniejące $\mathrm{w}$ człowieku napięcie wynikające z zawieszenia między tym, co ziemskie i niebiańskie. Intuicje Aleksandryjczyka dotykają tu bardzo często tych samych idei, do których dochodzi współczesna psychologia. Chociaż wizja człowieka jest u Orygenesa dosyć skomplikowana i niejasna, to jednak bez wątpienia posiada przede wszystkim biblijne inspiracje oraz bardzo dobrze pokazuje odniesienie i podobieństwo człowieka do Boga. Posiada ona także swoje trudności. Wydaje się, że słusznie zauważa T. Spidlik, iż poważnym problemem teologicznym jest rodzaj obecności Ducha Świętego w człowieku. Duch Święty według Orygenesa przychodzi do człowieka od Boga niejako z zewnątrz, a zarazem przynależy do ludzkiego ,ja” i jest zarazem równocześnie duchem w człowieku, czyli duchem człowieka i tak samo Duchem Świętym $^{66}$. Być może takie pytanie uzasadnione jest, gdy szukamy wizji ontycznej,

\footnotetext{
${ }^{61}$ Por. tamże, s. 307.

${ }^{62}$ Por. Szram, Ciało zmartwychwstałe, s. 285.

${ }^{63}$ Por. A. Lieske, Die Theologie des Logosmystik bei Origenes, Münster 1938.

${ }^{64}$ Por. A. Grillmeier, Gesù il Cristo nella fede della Chiesa. Dall'età apostolica al concilio di Calcedonia (451), Brescia 1982, 346.

${ }^{65}$ Por. Crouzel, Orygenes, s. 129.

${ }^{66}$ Por. Špidlik, Duchowość chrześcijańskiego wschodu, s. 132.
} 
a staje się niezwykłą głębią wschodniej tradycji teologicznej w wizji mistycznej. Orygenes przecież powie, że ,nie mniej niż Kościół świątynią Bożą ze swej natury jest wszelka rozumna natura, stworzona po to, by napełnić się chwałą Bożą" "67.

\section{ORIGEN'S TRICHOTOMIC ANTHROPOLOGY}

\section{(Summary)}

Origen was one of the greatest biblical scholars of the early Church, having written commentaries on most of the books of the Bible. He recognized great authority of the scripture. In anthropology he gave attention to the text of saint Paul: "May the God who gives us peace make you holy in every way and keep your whole being - spirit, soul, and body - free from every fault at the coming of our Lord Jesus Christ" (1Thess 5:23). According to this text Origen recognized in human being three elements. He tried to unite trichotomy with a concept of division of human being into two parts: interior and exterior man. Spirit in this concept is soul's teacher and a special form of participation in the divine being. In a sense spirit is ontological image of God in man and for man it is impossible to lose it. Soul is the center of man in which he makes decisions. Soul was originally created in close proximity to God, with the intention that it should explore the divine mysteries in a state of endless contemplation. The body unites man with the whole created world and gives him material aspect. Origen's anthropology is very complicated but more dynamic then static division on body and soul. If the soul is going to spirit, it become more spiritual, otherwise if the soul is close to the body, it become more materialistic. In this view without any doubt the human soul is posed between spirit and body and is able to acquiesce the desires of spirit but is able to let itself to be led by carnal desires, too. According to Origen man is body, because is creature, which dies, but through the body is able to communicate with material world. Man is soul because lives and is able to choose. Man is spirit because is open to God and is able to recognize and love God. Trichotomic anthropology shows that ontological and moral aspects of human being permeate each other and it demonstrates the interior drama and struggle, which always exists in man.

Key words: Origen, trichotomic anthropology, man, image of God, soul.

Słowa kluczowe: Orygenes, antropologia trychotomiczna, człowiek, obraz Boży, dusza.

${ }^{67}$ Origenes, Commentarii in Matthaeum 16, 23, PG 13, 1453, thum. K. Augustyniak, ŹMT 10, Kraków 1998, 312. 